The Law of Passing Off - goodwill beyond goods

\author{
Author: Catherine W. Ng \\ c.w.ng@abdn.ac.uk \\ +44 (0)1224273897 \\ University of Aberdeen \\ School of Law \\ Taylor Building \\ Old Aberdeen AB24 3UB \\ United Kingdom
}




\section{The Law of Passing Off - goodwill beyond goods}

Abstract: Claimants in England have no specific right to object to third party use of their personal identities. Where the fact scenarios appear to fit, claimants have brought actions under the law of passing off. The House of Lords once declared the English law of passing off as the 'most protean' among unfair trading wrongs for traders who suffer a resulting loss of business or goodwill. Until the recent cases of Irvine v. Talksport and Fenty v. Arcadia Group Brands Limited, claimants have not been successful. Has the law been rendered more protean with the recent extensions to cover, in these two cases respectively, false endorsement claims and false merchandising claims? This work takes a bifurcated view of the concept of goodwill to show that throughout the development of the English law of passing off, claimants are concerned with the protection not only of their trade at hand, and with distinguishing it from that of rival traders. Above all, claimants are concerned with the protection of their control over the aspect of their goodwill which garners their trade going forward. By increasingly taking a contextual approach in appreciating the public understanding of branding practices and applying it within the doctrinal framework of the law to address the claimants' fundamental concerns, the courts are treating the law of passing off with coherence and yet with relevance to contemporary commercial and social practices.

Keywords: passing off, goodwill, personality right, branding, instrumental value, intrinsic value

The House of Lords once declared the English law of passing off as the 'most protean' ${ }^{1}$ among unfair trading wrongs for traders who suffer a resulting loss of business or goodwill. While the law of passing off states that no trader is to pass off his or her goods as those of another, ${ }^{2}$ the current law in England does not protect traders only against counterfeiters. ${ }^{3}$ It is said to protect the claimant's trade goodwill from harm. ${ }^{4}$ The parameters of such goodwill have extended over time. Recent cases dealing with well-known personalities appear to have extended them further. This work aims to show that throughout the development of the English law of passing off, claimants are concerned not only with the protection of their trade at hand, but above all, with the protection of their control over the aspect of goodwill which garners their trade going forward. Brands

\footnotetext{
${ }^{1}$ Diplock LJ, Erven Warnink Besloten Vennootschap v. J Townend \& Sons (Hull) Ltd, [1979] AC 731 (HL), p. 740.

${ }^{2}$ Perry v. Truefitt, (1842) 5 Beav 66, 49 ER 749 (Ch); Oliver LJ, Reckitt and Colman Products Limited v. Borden Inc, [1990] 1 WLR 491 (HL), p. 499. For simplicity, 'goods' hereafter includes services, unless the context indicates or implies otherwise.

${ }^{3}$ Irvine v. Talksport, [2002] 1 WLR 2355 (Ch), pp. 2361 - 2363, paras. $18-21$.

${ }^{4}$ Ibid, p. 2366, para 34; Fenty v. Arcadia Group Brands Limited, [2015] 1 WLR 3291 (CA), p. 3300, para. 33; Starbucks (HK) Ltd v. British Sky Broadcasting Group Pls, [2015] 1 WLR 2628 (SC), p. 2635, para. 21.
} 
seek not only to distinguish their goods from those of others' instrumentally in the market place. They seek to retain and expand their ongoing influence on their clientele and prospective clientele through a more holistic intrinsic appeal in their goodwill. The contention here is that by increasingly taking a contextual approach within a doctrinal framework to address the claimants' fundamental concerns, the courts are treating the law of passing off with coherence and relevance. They are accounting for both the instrumental and intrinsic value in the goodwill of brands. This work takes this bifurcated view to analyse the claimant's goodwill under the law of passing off.

The analysis here will focus on the law of passing off where the disputed representation evokes the claimant's personal identity. As will be discussed later, ${ }^{5}$ the considerations here have broader application in the law. In the cases which evoke the claimants' personal identities, the claimants' concern over the control of the goodwill attached to their identity is most acute because personal identities are least alienable. Furthermore, these claimants' personal identities are inextricably bound up with their trade identities. These claimants are often known beyond a defined trade sector; they challenge the traditional confines of 'trade goodwill' in the law. In resolving disputes dealing with personal identities, recent courts have taken into consideration the social dynamics between consumers and the claimants' brands in the creation of goodwill in the marketplace.

In contrast to their counterparts in jurisdictions such as in the US, claimants in England have no specific right to object to third party use of their personalities. ${ }^{6}$ Where the fact scenarios appear to fit, claimants have brought actions under the law of passing off. After a series of failures, claimants have recently succeeded in Irvine v. Talksport ${ }^{7}$ and Fenty v. Arcadia Group Brands Limited. ${ }^{8} \quad$ Fenty concerns a well-known fashion retailer defendant selling T-shirts which bore the image of the pop star claimant Robyn Rihanna Fenty (professionally known as 'Rihanna'). With no other legal recourse, Fenty's passing off claim developed from the false endorsement claim in Irvine. Irvine involves the use of an altered photograph of well-known Formula One racer Eddie Irvine to advertise the defendant's sports radio station. Moreover, in Irvine the High Court noted:

\footnotetext{
${ }^{5}$ See text to infra notes $156-157$.

${ }^{6}$ See for example Walsh 2013; de Landa Barajas 2009; Vaver 2006; Klink 2003.

${ }^{7}$ Supra note 3; affirmed on merit [2003] 2 All ER 881 (CA). See also text to infra notes 108 - 117.

8 [2014] IP \& T 827 (Ch); affirmed [2015] 1 WLR 3291 (CA). See also text to infra notes $140-152$.
} 
no matter how irrational it may seem to a lawyer, those in business have reason to believe that the lustre of a famous personality, if attached to their goods or services, will enhance the attractiveness of those goods or services to their target market. ${ }^{9}$

As commonly accepted, ${ }^{10}$ the three basic elements of the English law of passing off which a claimant must establish are often abstracted to: first, a goodwill which arises from an association of the claimant's goods with the claimant's distinctive identifier (such as a brand name or logo) in the public's mind such that the public would recognise the claimant's goods by the identifier; second, a misrepresentation (whether or not intentional) by the defendant to the public which would lead or likely lead the public to believe that the defendant's goods are those of the claimant's; and finally, the damage or likelihood of damage to the claimant's goodwill from the erroneous belief would or likely result from the defendant's misrepresentation. ${ }^{11}$ This goodwill is commonly defined in the law of passing off as 'the attractive force which brings in custom'. ${ }^{12}$

This work argues that as recent courts are increasingly taking a contextual approach to the law, they are increasingly addressing goodwill in terms of what legal theorist Joseph Raz called the instrumental and intrinsic value in respect of the law he analysed. This work will start with a brief discussion of these terms with a brief reference to branding. It will then note the gradual movement in passing off decisions from a doctrinal approach towards a pragmatic approach guided by legal doctrines.

As a preliminary matter, it is worth noting that both the judge-made law of passing off and the UK trade marks legislation regulate branding. They are often applied within the same fact scenarios. ${ }^{13}$ Trade Marks Act 1994 ('TMA') is intended, inter alia, to implement the relevant EU Directive ${ }^{14}$ to approximate the laws of the Member States relating to trade marks. The protection it offers differs from that under the law of passing off. Passing off is not confined to that resulting from the use of registered trade marks. While the TMA protects

\footnotetext{
${ }^{9}$ Laddie J, Irvine (Ch), supra note 3, p. 2368, para 39; see also Fenty (CA), ibid, p. 3303, para 38.

${ }^{10}$ See for example Starbucks (HK) Ltd (SC), supra note 4, p. 2633, para 15.

${ }^{11}$ Reckitt and Colman Products Limited, supra note 2, p. 406.

${ }^{12}$ Inland Revenue Commissioners v. Muller \& Co's Margarine Ltd, [1901] AC 217, p. 224, also cited in Breyer Group Plc v. Department of Energy and Climate Change, [2015] 1 WLR 4559 (CA), pp. 4576 - 4577, para. 44. See also text at infra notes $66-75$.

${ }^{13}$ Trade Marks Act 1994, Sec. 2(2). See for example Arsenal v. Reed, [2001] RPC 46 (Ch) where claims were filed under both the law of passing off and Trade Marks Act 1994; the claim for passing off failed, while the claim for trade mark infringement was referred to the ECJ. On the passing off claim, see text at infra notes 132 - 138. See also Ni Shuilleabhain 2003.

14 Trade Marks Act 1994, preamble; Council Directive No 89/104/EEC of 21 December 1988; now Directive 2008/95/EC of the European Parliament and of the Council of 22 October 2008 ('TMD'). See also infra note 22.
} 
trade marks as property immediately upon registration, ${ }^{15}$ the law of passing off is said to protect as property the trade goodwill that develops in the marketplace. ${ }^{16}$ To constitute the tort, passing off further requires misrepresentation leading to confusion among a relevant public and potential resulting harm to the claimant's goodwill. Trade mark infringement, under the TMA and the corresponding EU Directive, requires no public confusion in cases where the disputed marks are identical and used for identical goods (double identity), ${ }^{17}$ and in cases where the claimant's mark has a reputation and the disputed use of the mark or a similar mark without due cause would take unfair advantage of or be detrimental to the distinctive character or repute of the mark (dilution). ${ }^{18}$ Trade mark infringement requires public confusion or its likelihood where identical marks are used for similar goods or where similar marks are used for identical goods between the parties. ${ }^{19}$ Conceptual issues ensue in view of the overlaps among these categories of statutory protection. ${ }^{20}$ The set of trade mark functions (including the origin function, the advertising function, investment function, communication function) ${ }^{21}$ that the Court of Justice of the European Union has derived, and that these provisions are said to protect, has created uncertainties as to how these functions ought to be applied, the vagueness in the meaning of the functions, and the open-ended nature of this list of functions. ${ }^{22}$ This work is however focussed on the protection of goodwill from a particular type of misrepresentation in passing off, rather than the protection of a defined mark.

\section{Legal theory - as applied to branding:}

What underpins the law of passing off may be seen through Raz's conception of the instrumental and intrinsic value in the law that he analyses, but applied in this work to branding. Raz's analysis concerning personal and collective identities, as set out in his essays in Between Authority and Interpretation, ${ }^{23}$ is

\footnotetext{
15 Trade Marks Act 1994, Sec. 2.

${ }^{16}$ Starbucks (HK) Ltd (SC), supra note 4, p. 2635 para. 21; Irvine (Ch), supra note 3, p. 2366, paras. 32 - 34. See also infra note 41.

17 Trade Marks Act 1994, Sec. 10(1) in relation to TMD, Art. 5(1)(a).

18 Trade Marks Act 1994, Sec. 10(3) in relation to TMD, Art. 5(2).

19 Trade Marks Act 1994, Sec. 10(2) in relation to TMD, Art. 5(1)(b).

${ }^{20}$ See for example regarding double identity: C-206/01 Arsenal Football Club Plc v Reed, [2003] Ch 454 (CJEU), p. 460, para. 27; C-323/09 Interflora Inc v. Marks \& Spencer Plc, [2012] Bus LR 1440 (CJEU), pp. 1146-1147, para. 20, p. 1148, paras. 27, 28; Senftleben 2014; regarding dilution C-487/07 L'Oréal v Bellure [2010] Bus LR 303 (CJEU), p. 314, para. 30; C-408/01 Adidas Salomon AG v Fitnessworld Trading Ltd, [2004] Ch 120 (CJEU), p. 123, para. 12; see also Kur 2014; Dinwoodie 2013.

${ }^{21}$ See for example Arsenal Football Club Plc (CJEU), ibid, pp. 466 - 468, paras. 48 - 51; C-323/09 Interflora Inc v. Marks \& Spencer Plc, supra, note 20, pp. 1449-1454, paras. 34 - 66, C-487/07 L'Oréal (CJEU), ibid, p. 322 , paras. 58, 60 .

${ }^{22}$ Blythe 2015; Kur 2014; Senftleben 2014; Dupont 2013; Cornthwaite 2012; Chronopoulos 2011; Yap 2009. See also Directive (EU) 2015/2436 of the European Parliament and of the Council of 16 December 2015 to approximate the laws of the Member States relating to trade marks (Recast), p. L336/3, preamble paras. 16, 18 20; Senftleben et al 2015.

${ }^{23} \mathrm{Raz} 2009$. He is not the only author to have advanced some of the ideas here; see most notably Hart 2012, Dworkin 1998. Earlier edition or printing of these works (among others) is referred to in Raz 2009, for example
} 
particularly pertinent because modern branding similarly draws on such identities. ${ }^{24}$ Both law and brands seek to influence their constituents. Brands do so through the utility of their underlying goods, and the personal and collective interpretations of the social meanings and values imbued in the brands and their goods. The law may do so by the authority of its institutions and by the rights and duties enforced by way of regulatory, civil, and criminal sanctions that these institutions may impose. Nevertheless, both seek to exert influence, and may do so by gaining acceptance among their constituents

Raz responds to the question of why an individual would be subject to the will of another under the law, with the service conception, ${ }^{25}$ that is, a subject may have other reasons than the law to behave in a way required by the law. A subject may also judge that conformance with the law would remove the need for individual experimentation, reasoning, and decision making, ${ }^{26}$ and ultimately avoid social conflicts otherwise caused by the subject's own assertions. The law is all the more compelling where constituents identify with it and where it is consonant with their broader political and social reality. ${ }^{27}$ That reality includes the social values which inform the substantive contents of the law and the social values upon which institutions are founded to formulate, recognise, implement, and enforce the law.

On the one hand the role of authority is to enable people better to conform to reason, that is to make it more likely that they will, given good will, conduct themselves as reason requires. To that extent the law is to be treated essentially instrumentally. On the other hand, in being partly constitutive of a community which is normally a focus of identification, the law can be intrinsically valuable. ${ }^{28}$

Instrumentally, the law seeks to mould the conduct of and the social relations among its constituents. As individuals, these constituents seek a sense of self-respect, self-worth, and a sense of orientation in their environment by belonging to various communities which they respect and with which they identify. Guided by emotions and judgement, they may accept as their own the standards that those communities endorse. 'Given the importance of political communities in the life of their members, an ability to identify with one's political community is ... intrinsically valuable. ${ }^{29}$ Through its instrumental and intrinsic value, the law can mobilise its constituents to achieve social conditions which depend on the collective action of a critical mass; such action

respective note 5 at p. 19 and note 14 at p. 34 therein. See also Balganesh and Parchomovsky 2015; Brudner 2013; MacCormick 2005.

${ }^{24}$ See for example Wolter et al 2016; Breazeale and Fournier 2012, p. 404; Edvardsson et al (2011).

${ }^{25}$ Raz 2009, pp. 136 - 137 (footnote omitted).

${ }^{26}$ Ibid, pp. 7, 110, $137-142$.

${ }^{27}$ Ibid, p. 152.

${ }^{28}$ Ibid, p. 112.

${ }^{29}$ Ibid, p. 106. 
may in turn move others to conform. ${ }^{30}$ The law can then coordinate diverse social interests to address moral concerns and advance economic and social agendas. ${ }^{31}$ The law becomes an artefact of a collective identity; it in turn informs that collective identity by formalising part of its social norm to become social facts which are endorsed by the competent legal authority. ${ }^{32}$ Constituents may point to the law as a social fact which demands conformance to achieve certain social conditions, and position themselves in relation to that social fact. Their positioning influences others who identify with them and who may adopt the standards they endorse.

\subsection{Branding}

Similarly, brands can have instrumental and intrinsic value which influences their target markets. 'A brand is much more than merely a "legally defensible proprietary name" and it serves more than as a differentiating device, indicating source: brands are essentially identity systems, encompassing a personality, a relationship, and an image in consumers' minds. ${ }^{33}$ Purchase decisions are driven by both reason and emotion. '[P]roducts are carriers of socially shared symbolic meanings that manifest themselves in cognitive and behavioural reactions that are guided by a multiplicity of motives, specifically including emotions and social aspirations, and not only by a "rational" cost-benefit assessment." ${ }^{34}$ Brands use indicia to distinguish the goods of one trader from those of other traders. Instrumentally, the indicia identify for consumers the goods which, 'as reason requires', may be functionally more fitting than others for the consumers' use. They help consumers avoid experimentation with purchase decisions - they help consumers identify repeat purchases or recommended purchases. They also minimise social risks. For example, McDonald's reassuringly declares on the pylons at many of its fast food restaurants the 'billions [of customers] served'. Furthermore, as with law, brands are imbued with social meanings and values. These social meanings and values form the basis for the intrinsic value in a brand. In the case of McDonald's, these social meanings and values derive from, inter alia, the goods offered, the promotional efforts, and the ambience of the service venue. ${ }^{35}$ They also derive from the clientele attracted to the brand. McDonald's customers are identifiable by the GOLDEN ARCHES ${ }^{36}$ on the

\footnotetext{
${ }^{30} \mathrm{Ibid}$, p. 342.

${ }^{31}$ Ibid, pp. 178 - 181, $192-193,342,346-348$.

32 Ibid, pp. $99-115$.

${ }^{33}$ Schwarzkopf 2010 , pp. $165-166$.

${ }^{34}$ Ibid, pp. 173 - 176 (references omitted). See also Davis and Maniatis 2010, p. 124.

${ }^{35}$ Corporate Design Foundation 2006-2007.

${ }^{36}$ See for example issued to McDonald's International Property Company, Ltd Trade Mark UK00001285808 for Class 43 for restaurant services http://www.ipo.gov.uk/tmcase/Results/1/UK00001285808 accessed $28 \mathrm{March}$ 2016; Trade Mark UK00001115186 for Class 16 which includes printed matter; paper and cardboard products, and Class 28 for games (other than ordinary playing cards), toys, and playthings http://www.ipo.gov.uk/tmcase/Results/1/UK00001115186 accessed 28 March 2016; Trade Mark UK00001044476 for Class 30 which includes coffee, tea, sandwiches, and seasonings
} 
goods they carry out. Brands and their consumers as a collective inform and nourish each other's identities, in contradistinction against those who embrace different social values, ${ }^{37}$ and therefore select different goods or different brands. Brands also select role models with whom their target markets would identify. As part of its 'Forever Young' rebranding campaign to reach health conscious young adults, McDonald's clown mascot, Ronald McDonald, appeared in Olympics advertisements and also with sports stars such as Yao Ming, Serena Williams, and Venus Williams. ${ }^{38}$ Brands use their indicia-bearing mascot or spokespersons, role models and customers to cast themselves as 'partly constitutive of a community which is normally a focus of identification. ${ }^{39}$ Consumers too use brands to help negotiate their sense of identity, social belonging or aspirations.

If we use 'names' as handles for grasping the more hidden cognitive processes synthesising consumption, and if we view goods and their names as the accessible parts of an information system, the consumer's problem in achieving his life-project becomes clearer. He needs goods to give marking services and to get marking services; that is, he has to be present at other people's rituals of consumption to be able to circulate his own judgements of the fitness of the things used to celebrate the diverse occasions. ${ }^{40}$

He would also be able there to formulate his own judgement of the fitness of that consumer as representative of a community with which he would identify and whose endorsed goods he would adopt for himself. Brands may thereby further exert their appeal.

\section{Passing Off}

While the law of passing off has long recognised the instrumental value in brands, it has only recently come to recognise their intrinsic value explicitly where the brand appeal reaches across diverse trade sectors. The founding principle of the law that no trader may pass off his or her goods as those of another enforces the brands' instrumental value in distinguishing the goods which may serve the consumers' utilitarian needs. The goodwill element requires that the relevant public has prior familiarity with the claimant's brand. ${ }^{41}$ While the law may instrumentally protect repeat and recommended purchases, it may also protect an intrinsic value

http://www.ipo.gov.uk/tmcase/Results/1/UK00001044476 accessed 28 March 2016; Trade Mark

UK00001026605 for Class 29 for hamburgers, cheeseburgers, French fried potatoes, milk, milkshakes, and cooked chicken http://www.ipo.gov.uk/tmcase/Results/1/UK00001026605 accessed 28 March 2016.

${ }^{37}$ Schmitt 2012.

${ }^{38}$ Light and Kiddon 2009, p. 137.

${ }^{39}$ Supra note 28.

${ }^{40}$ Douglas and Isherwood 1979, p. 81. See also Bourdieu 1991, pp. 220, 223-224.

${ }^{41}$ Inland Revenue Commissioners, supra note 12, p. 224 '[goodwill] is the one thing which distinguishes an oldestablished business from a new business at its first start. ... goodwill is worth nothing unless it has power of attraction sufficient to bring customers home to the source from which it emanates.' See also, for example Irvine (Ch), supra note 3, pp. 2369 - 2370, para. 46. 
cultivated through the social dynamics in the marketplace between consumers and brands along with the individuals who are perceived to be associated with these brands. In this light, the intrinsic value in brands involves more than a reputation that is received and assessed by the relevant public in a defamation sense. It engages with the sense of identity and social belonging or aspiration of the relevant public in a way that would influence business decisions. The decision maker's own identity is at stake. However, until recently, the law of passing off has not fully acknowledged the claimants' desire to regain this intrinsic value brands enjoy to influence business decision. Much of this gap arose from the doctrinal limitations in conceptualising the goodwill protected under the law. Much of the current closing of this gap is attributable to the increasing judicial attention paid to the public interactions with branding practices in the marketplace. This development recently coincides with an emerging human rights discourse involving privacy rights, rights to freedom of expression, and property rights. This discourse may be viewed as what Raz might identify as a part of the broader political and social reality within which the law operates. It forms a backdrop that appears consonant with the recent more holistic approach to the law of passing off. The UK Human Rights Act 1998 was introduced in October $2000^{42}$ to provide further domestic consideration ${ }^{43}$ of the rights addressed in the European Convention for the Protection of Human Rights and Fundamental Freedoms ${ }^{44}$ (ECHR) and buttressed in the Charter of the Fundamental Right of the European Union. ${ }^{45}$ The Charter came into force under the Lisbon Treaty in December 2009. In this light, the emerging human rights jurisprudence may also shed light on certain recent developments in the law of passing off.

\subsection{Early conceptualisation of goodwill}

The passing off claimants' concerns extend beyond economic loss; they generally prefer injunctive relief over monetary relief. While an award of damages would address the loss of revenue from the passing off, injunctive relief allows claimants to regain their intrinsic value in the brand to influence their clientele and prospective clientele. It is arguably at least in part the early claimants' desire for injunctive relief which gave the tort its proprietary character. That characterisation remains with the goodwill element in the law to-day. ${ }^{46}$ This characterisation and its boundaries however also limited claimants from gaining a fuller protection of the intrinsic value in their brands under the law.

\footnotetext{
${ }^{42}$ See also Vaver 2006.

${ }^{43}$ Hale 2013.

${ }^{44}$ Rome, 4 XI 1950.

${ }^{45}$ Arts. 7, 17, and 11 respectively. See also Griffiths 2015; Geiger 2009.

${ }^{46}$ Starbucks (HK) Ltd v. British Sky Broadcasting Group Plc, [2014] IP \& T 128 (CA), p. 147, para. 103, affirmed (SC) supra note 4.
} 
At the time that the term 'pass off' first appeared in the headnote of the 1842 case of Perry $v$. Truefitt, ${ }^{47}$ the Courts of Chancery alone had jurisdiction to grant injunctive relief. They also had clear jurisdiction to uphold proprietary interest, ${ }^{48}$ as they did in aid of evident legal rights. Perry was a classic goods-for-goods substitution case. The plaintiff there claimed the defendant's use of TRUEFITT'S MEDICATED MEXICAN BALM would be injurious to PERRY'S MEDICATED MEXICAN BALM which enjoyed extensive sales and repute, and asserted that the public would be deceived by the similarity in the names. Lord Langdale as Master of the Roll stated:

whether he has or not a property in the name or the mark, I have no doubt that another person has not a right to use that name or mark for the purposes of deception, and in order to attract to himself that course of trade, or that custom, which, without that improper act, would have flowed to the person who first used, or was alone in the habit of using the particular name or mark. ${ }^{49}$

However later in Clark v. Freeman ${ }^{50}$ brought by an apparent endorser who was not in trade, Lord Langdale declined jurisdiction. Sir James Clark, who was Physician in Ordinary to Her Majesty and specialised in consumption, sued the defendant for selling pills called SIR JAMES CLARKE'S CONSUMPTION PILLS and for publishing advertisements commencing with ‘By Her Majesty the Queen’s permission, Sir James Clarke’s Consumption Pills'. There was no other Sir J Clark in the practice of medicine in England at the time. Clark pleaded fraud and claimed injury to his professional character with loss to his income. While disapproving of the defendant's act as potentially libellous, Lord Langdale found no interest for his court to protect because Clark neither manufactured nor sold pills. ${ }^{51}$ In Perry even though proprietary interest was not established there, the law of passing off was called upon to protect the instrumental value in the plaintiff's name and to distinguish its goods from the defendant's, and thereby to protect the plaintiff's extensive intrinsic value from exploitation. In Clark, the plaintiff had no instrumental value at stake because he was not in trade; he was implicated in the defendant's trade arguably only for the intrinsic value in his professional status - the defendant used Clark's status as Physician in Ordinary to the Queen and a specialist in consumption to attract the public to the

\footnotetext{
${ }^{47}$ Perry, supra note 2, pp. 73, 752.

${ }^{48}$ Hall v. Barrows, (1863) 4 De Gex, Jones \& Smith 150, 46 ER 873 (Ch); Edelsten v. Edelsten, (1863) 1 De Gex Jones \& Smith 185, 46 ER 72 (QB).

${ }^{49}$ Perry, supra note 2, pp. 73, 752.

${ }^{50}$ (1848) 11 Beav 112, 50 ER $759(\mathrm{Ch})$.

51 Ibid, pp. 119, 762.
} 
defendant's consumption pills. Lord Langdale's decision in Clark was later largely discredited: ${ }^{52}$ 'Could not a professional man be injured in his profession by having his name associated with a quack medicine? ${ }^{53}$

It proved conceptually difficult to capture in law this intrinsic value in brands. Mindful of proprietary models in pre-existing copyright ${ }^{54}$ and emerging registered trade marks, ${ }^{55}$ early courts were circumspect in determining where the proprietary interest for passing off should lie. Lord Westbury who was Lord Chancellor from 1861 to 1865 found that fraud in the defendant was not necessary for the exercise of jurisdiction at Chancery. ${ }^{56}$ However:

Imposition on the public is indeed necessary for the Plaintiff's title, but in this way only, that it is the test of the invasion by the Defendant of the Plaintiff's right of property; for there is no injury if the mark used by the Defendant is not such as is mistaken, or is likely to be mistaken, by the public for the mark of the Plaintiff; but the true ground of this Court's jurisdiction is property, and the necessity of interfering to protect it by reason of the inadequacy of the legal remedy. ${ }^{57}$

The likelihood of consumer confusion of the defendant's mark for the plaintiff's was a proxy for the potential proprietary harm to the plaintiff and possibly gain for the defendant. ${ }^{58}$ Consumers had $^{59}$ and still have no right of action under the tort. Lord Westbury's notion of property meant an exclusive right to use one's name or mark on a particular manufacture or vendible commodity. ${ }^{60}$ It did not lie in the mark on its own but in the acceptance and currency gained by that mark as applied to an article in the marketplace. ${ }^{61}$ Lord Cranworth later stated the proprietary interest would lie in an exclusive right to use a mark for the purpose of indicating where, by whom, or at what manufactory the underlying goods were manufactured. ${ }^{62}$ While value was attached to 'goodwill', the

\footnotetext{
${ }^{52}$ For example Hogg v. Maxwell, (1866-67) LR 2 Ch App 307, p. 310; Springhead Spinning Company v. Riley, (1868) LR 6 Eq 551; Dixon v. Holden, (1868-69) LR 7 Eq 488; Walter v. Ashton, [1902] 2 Ch 282.

${ }^{53}$ Seldon LJ in obiter, Re Rivière's Trade-mark (1884) 26 ChD 48 (CA), p. 53.

${ }^{54}$ See Sherman and Bently 1999, pp. 166-172.

${ }_{55}$ Bently 2008, pp. 16-27. See also Trade Marks Registration Act, 1875, Sec. 3.

${ }^{56}$ Hall, supra note 48, pp. $156,876$.

${ }^{57}$ Ibid, 159, 877; see also The Leather Cloth Company v. The American Leather Cloth Company, Limited, (1863) 4 De Gex, Jones \& Smith 137, 46 ER 868 (Ch).

${ }^{58}$ Hall, supra note 48, pp. 159, 877; later Singer v. Loog, (1882) LR 8 (HL), pp. 13, 39. See also Irvine (Ch), supra note 3, p. 2361, para. 18.

${ }^{59}$ Webster v. Webster, (1791) 2 Swans 492, 36 ER 949 (Ch).

${ }^{60}$ Hall, supra note 48, pp. 158-159, 877; The Leather Cloth Company (Ch), supra note 57, pp. 142, 144, 870871.

${ }^{61}$ Edelsten, supra note 48, p. 201; Hall, supra note 48, pp. 876-877, 157-159; The Leather Cloth Company (Ch), supra note 57, affirmed (1865) XI HL 523, 11 ER 1435 (Lord Westbury); M'Andrew v. Bassett, (1864) 4 De Gex, Jones \& Smith 380, 46 ER 965 (Ch); Wotherspoon v. Currie, (1871-72) LR 5 (HL) 508, p. 522.

${ }^{62}$ The Leather Cloth Company (HL), ibid, pp. 533-534, 1440.
} 
meaning of that term within a passing off context remained conceptually difficult. ${ }^{63}$ The 1875 trade mark legislation which introduced trade mark registration in the United Kingdom recognised proprietorship in trade marks. ${ }^{64}$ However it was not until 1915 that the House of Lords in Spalding v. Gamage finally settled that the proprietary interest to be protected under passing off lied with the goodwill engendered by the goods or the business as conveyed by the associated mark. ${ }^{65}$ Such goodwill, then defined as "the attractive force which brings in custom', ${ }^{66}$ had already gained acceptance as 'property' within other legal contexts, for example in tax and in the sale or valuation of businesses. ${ }^{67}$

However, this goodwill captures a snapshot of the commercial value of the property, the instrumental value in a brand. It does not address the intrinsic value that claimants also seek to protect in their brands under the law of passing off. The same definition is used today within a human rights context with respect to the property right in goodwill. ${ }^{68}$ Art. 1 of Protocol 1 to the ECHR states: 'Every natural or legal person is entitled to the peaceful enjoyment of his possession'. While goodwill and other property rights are recognised as 'possessions' ${ }^{69}$ goodwill here is limited to accrued income or that within a 'legitimate expectation' at a relevant date. It excludes market share ${ }^{70}$ and other future income and control over such income. ${ }^{71}$ The article protects "'goodwill", as a form of asset with a snapshot monetary value, and does not protect an expected stream of future income which, for mainly organisational reasons, cannot be or is not capitalised. ${ }^{72}$ The precise division

\footnotetext{
${ }^{63}$ See for example Wedderburn v. Wedderburn (No. 4), (1856) 22 Beav 84, 52 ER 1039 (Ch); Churton v. Douglas, (1859) VC Johnson 174, 70 ER 385 (Ch); Lord Cranworth, The Leather Cloth Company (HL), ibid, p. 533, 1440; Wadlow 2011, pp. 23 - 24, paras. 1-037, pp. 32 - 33, 1-048; Bone 2006, pp. 569-570; McKenna 2006-2007, p. 1886.

${ }^{64}$ See supra note 55.

${ }^{65}$ (1915) 32 RPC 273 (HL) $284-285$.

${ }^{66}$ Inland Revenue Commissioners, supra note 12.

${ }^{67} \mathrm{Ibid}$; Wedderburn, supra note 63.

${ }^{68}$ First Protocol to the ECHR art 1 (Paris, 20 III 1952); Sermet 1998; Charter of Fundamental Rights of the European Union (2000/C 364/01) art 17; DaimlerChrysler AB v. Javid Alavi, [2001] RPC 42, p. 813 (Ch), pp. 847 - 848, paras. 107 - 109; Boehringer Ingelheim Limited v. Vetplus Limited, [2007] Bus LR 1456 (CA), p. 4165 , para. 37.

${ }^{69} R$ (Nicholds) v. Security Industry Authority, [2007] 1 WLR 2067 (Admin), pp. 2085 - 2086, paras. 71 - 73.

${ }^{70} \mathrm{C}-154 / 04$ and C-155/04 R (On the Application of Alliance for Natural Health and Another) v. Secretary of State for Health, [2005] 2 CMLR 61, 1490 (ECJ (Grand Chamber)), p. 1535, para. 128; C-210/03 Swedish Match AB and Swedish Match UK v. Secretary of State for Health, [2004] ECR I-11893 (ECJ (Grand Chamber)), para. 78.

${ }^{71}$ Anheuser-Busch Inc v. Portugal 73049/01, (2007) 23 BHRC 307 (ECtHR (Grand Chamber)) in respect of a trade mark application; $R$ (Countryside Alliance and others) v. Attorney General, [2008] 1 AC 719 (HL), p. 747, para. 21, the issue was not considered at ECtHR in 16972/06 Friend v. UK, 27809/08 Countryside Alliance v. $U K$, (2010) 50 EHRR SE6 61 (ECtHR), p. 78, para. 55; $R$ (Guildhall College Ltd) v. Secretary of State for Business Innovation and Skills, 2014 WL 3387837 (CA), p. 14, paras. 70, 72; R (Malik) v. Waltham Forest NHS Primary Care Trust, [2007] 1 WLR 2092 (CA), Auld LJ - pp. 2097 - 2101, paras. 21 - 29, p. 2013, para. 40, p. 2015, para. 45, Rix LJ - pp. 2107 - 2114, paras. 54 - 75, affirmed 23780/08 Malik v. UK, [2012] ECtHR 438. ${ }^{72} R$ (Nicholds), supra note 69, p. 2086, para. 73.
} 
line remains unclear. ${ }^{73}$ Nevertheless, the Court of Appeal has concluded in obiter that 'the attractive force which brings in custom ${ }^{, 74}$ where it pertains to the trader's reputation or past clients' loyalty would not be a 'possession' under Art. 1 Protocol 1 of the ECHR. ${ }^{75}$ This definition of 'goodwill' does not fully capture the forward looking intrinsic value in brands - what the claimants in Clark and more recently in Irvine and Fenty sought to protect.

\subsection{Goodwill in quality or class}

As brands seek to engage their clientele and prospective clientele with a sense of identity and social belonging or aspiration, they look to expand their points of engagement to more comprehensively embrace the lifestyles and social values of their target markets. They diversify and tailor their offerings to their target markets. While Spalding settled that property rights lied with trade goodwill in passing off, it also recognised that goodwill attracted customers in a way beyond Lord Cranworth's conception of indicating the trade origin of the underlying goods. ${ }^{76}$ The defendant in Spalding sold goods manufactured by the plaintiff and bore the plaintiff's trade marks. Those goods, having been found substandard by the plaintiff, had been withdrawn and sold to waste rubber merchants. The defendant purchased the goods from the waste rubber merchants and resold the goods at retail for their initial intended use under the plaintiff's original mark. There was no misrepresentation as to trade origin. Nevertheless, the court found the proposition that no one had a right to represent his goods as the goods of another must implicate the corollary that no one had a right to represent the goods of one quality or class to be the goods of a different quality or of a different class. ${ }^{77}$ The claimant's goodwill protected under passing off signalled to the relevant public not only the source of the goods, but also the quality or class of the goods. 'Extended passing off' eventually acknowledges that goodwill may be shared among different enterprises which offer goods of a particular quality or class. ${ }^{78}$ Permitting trade marks to be used by diverse sources of goods has become conceivable where these goods are of a particular quality or class.

\footnotetext{
${ }^{73}$ Bhasin 2012.

${ }^{74}$ Inland Revenue Commissioners, supra note 12, also cited in Breyer Group Plc v. Department of Energy and Climate Change, supra note 12, p. 4576-4577, para. 44.

${ }^{75} R$ (Malik)(CA), supra note 71, p. 2116, para. 86, cf Anheuser-Busch Inc, supra note 71, Caflisch and Cabral Baretto JJ dissent - p. 331, para. 3: that clientele and reputation are rights and interests protected by law in respect of the legitimate expectation created by the filing of a trade mark application. See also Breyer Group Plc, supra note 12, p. 4576, para. 43.

${ }^{76}$ The Leather Cloth Company (HL), supra note 61, pp. 533-534, 1440; see also text to supra note 62.

${ }^{77}$ AG Spalding, supra note 65.

${ }^{78}$ Erven Warnink Besloten Vennootschap, supra note 1; Dawnay Day \& Co Ltd v. Cantor Fitzgerald International, [2000] RPC 669 (CA): Fage UK Limited v. Chobani UK Limited, [2014] FSR 29 (CA).
} 
This conceptual shift opened the way for traders to extend their brand protection beyond product segments to market segments. ${ }^{79}$ 'Social lives have things'; 'things have social lives'. ${ }^{80}$ The more the claimants' and the consumers' social identities are intertwined through the claimants' branded goods, the higher the claimants' intrinsic value in their brands, the less fungible its goodwill. ${ }^{81}$ This occurs particularly where the consumers' sense of personal identity, social belonging or aspiration is closely tied with the consumption of particular brands of goods. This tie is fostered through branded goods which embrace the lifestyle and social values of the target market. For example, McDonald's restaurants offer co-branded games for children as promotional items, ${ }^{82}$ and support Ronald McDonald House Charities which promotes children welfare. ${ }^{83}$ These diverse ventures unrelated to the food industry imbue the brand with a coherent set of social meaning and values for a target market (in the case of McDonald's, its traditional toddlers-and-parents market) to identify with the brand, and for the brand to garner intrinsic value thereby. Crucially, the conceptual shift allows traders to extend their goodwill beyond their specialised trade, to leverage their goodwill from one trade to another so long as they appear to their relevant public to be retaining control over the quality and their classes of goods.

\subsection{Goodwill across trade sectors}

However, third party exploitation of this goodwill across trade sectors, by non-rival traders, was not recognised by the law of passing off because it was seen to lie beyond the conceptual bounds of the claimant's proprietary interest. In the 1947 case of McCulloch v. Lewis A May (Produce Distributors) Ltd, ${ }^{84}$ a children's radio programme personality was denied relief when his public persona 'Uncle Mac' was arguably evoked for UNCLE MAC breakfast cereal. Under the initial goods-for-goods substitution model of passing off where the claimants' customers would be lost to the defendants' rival trade, the parties shared a common field of trade. Given the diversity of trade between a radio personality and a breakfast cereal in this case, the court commented 'If it were anything, it were libel' ${ }^{85} \mathrm{~A}$ common field of trade between the parties appeared to be a requirement to constitute the tort.

\footnotetext{
${ }^{79}$ See also Schwarzkopf 2010, pp. 183 - 188; Davis and Maniatis 2010, pp. 121, $124-125$.

${ }^{80}$ Lury 2007, pp. 10, 18, referencing Appadurai A (1986) The social life of things: commodities in cultural perspective. Cambridge University Press, Cambridge.

${ }^{81}$ See also Radin 1981-1982, pp. 986 - 988, 1007 - 1013.

${ }^{82}$ See supra note 36; for example with Hasbro http://www.mcdonalds.co.uk/content/dam/McDonaldsUK/Promotions/Happy\%20Meal/Hasbro\%20Family\%20 Games/Hasbro-Keeko-Colouring-Sheet.pdf. Accessed 28 March 2016.

${ }^{83}$ See http://www.rmhc.org.uk/. Accessed 28 March 2016.

${ }^{84}$ [1947] 2 All ER 845 (Ch).

${ }^{85}$ Ibid, p. 851 .
} 
To overcome this requirement, courts have taken a contextual approach. This approach takes account of the social dynamics between brands and their relevant public, and thereby the intrinsic value the brands hold for their relevant public. In the 1970 s while having disputing parties operate within a common field of trade was increasingly rationalised as a condition in the marketplace under which the public would be more likely confused between the goods of these parties, ${ }^{86}$ the issue remained an obstacle for protection against those who merchandised using the claimants' identities, fictional characters or their facsimiles. The court's decision made no reference to any evidence from the marketplace in one 1975 case $;{ }^{87}$ and in another, the evidence for passing off in the false merchandising claim which extended beyond a common field of trade appeared 'a good long way off, if in fact it ever does arise'. ${ }^{88}$ In the 1976 case where images of the pop group ABBA were used for the defendant's merchandising, the court found the 'common field of activity' merely a shorthand term to indicate a real possibility of confusion.

This necessity, the need to show that reasonable people might think that the plaintiffs' activities were associated with the defendants' goods or business, at least to the extent of implying some sort of approval on the part of the plaintiff, is something which might $\ldots$ be said to cause damage to the plaintiffs... ${ }^{89}$

In this case, the court found the plaintiffs had no business within the jurisdiction which would be confused with the defendants'. Furthermore, although evidence in the case suggested that some members of the public might have thought ABBA had granted license for the use of the name, why they should do so appeared inexplicable to the court for want of evidence of 'any general custom for such licenses to be granted by pop singers' ${ }^{90}$ Interlocutory relief was denied. Nevertheless, the court appeared open to consider the public understanding of branding practices. Also by this time, there was judicial recognition that harm to reputation rather than loss of sales was the main concern for claimants seeking injunctive relief under passing off because harm to their reputation would be unquantifiable. ${ }^{91}$

By 1990, the court noted the increasing sophistication of the merchandising industry ${ }^{92}$ in a case where the defendant sought to take advantage of the plaintiffs' popular concept of humanoid turtle cartoon characters ${ }^{93}$

\footnotetext{
${ }^{86}$ Annabel's (Berkeley Square) Limited v. G Schock, [1972] FSR 261 (CA), p. 269 - not a merchandising case.

${ }^{87}$ Wombles Limited v. Wombles Skips Limited, [1975] FSR 488 (Ch), pp. 490-491.

${ }^{88}$ Tavener Rutledge Limited v. Trexapalm Limited, [1975] FSR 479 (Ch), p. 485.

${ }^{89}$ Lyngstad v. Anabas Products Ltd, [1977] FSR 62 (Ch), p. 67.

${ }^{90}$ Ibid, p. 68.

91 Annabel's (Berkeley Square) Limited, supra note 86.

${ }_{92}$ Mirage Studios v. Counter-Feat Clothing Co Ltd, [1991] FSR 145 (Ch), p. 148.

${ }^{93}$ Ibid, p. 150.
} 
and produced clothing with similar drawings. The court found the relevant public would expect items bearing such popular characters as the plaintiffs' to have been merchandised by the copyright owner. Where the public would mistake the defendant's goods for the plaintiffs' or as having been licensed by the plaintiffs, passing off was established. ${ }^{94}$ Here, both parties were in the business of licensing the right to use cartoon characters. The law was not limited to those who marketed or sold the goods themselves. ${ }^{95}$ A few years later, there was judicial recognition that the crux of the law of passing off lied with 'the relevant connection ... by which the plaintiff would be taken by the public to have made themselves responsible for the quality of the defendant's goods or services. ${ }^{96}$ This relevant connection may suggest both instrumental and intrinsic value where the plaintiff is known for having expertise in the quality of such goods. The force of the intrinsic value alone is more apparent where it can leverage the goodwill to influence purchase decisions in a different trade sector. Third parties, such as the defendant in $A B B A$, might capitalise on this intrinsic value for merchandising, and cause the public to attribute the quality of the defendant's goods as the plaintiff's.

Notwithstanding decisions such as $M c C$ ulloch and $A B B A$, the law has long protected certain non-trade claimants by overcoming any requirement of a common field of trade between disputing parties. In doing so, it arguably protects the intrinsic value for these particular claimants. These claimants tend to be professional and trade governing and promoting bodies, charities and like non-profit organisations. In many cases these bodies also provide public quality assurance by certifying a standard of knowledge among their members. Such membership confers an additional status for the profession. ${ }^{97}$ In other cases as in some charities, membership is loosely organised. ${ }^{98}$ Where the benefactors of these organisations' work are also the beneficiaries of their work, passing off may be more readily established in instrumental terms. ${ }^{99}$ Even where the goodwill engendered by these organisations is not aimed at generating revenue, courts have rationalised harm to trade goodwill in terms of a potential loss of membership and the associated fees in some cases, ${ }^{100}$ and loss of donation or sponsorship

\footnotetext{
${ }^{94}$ Ibid, p. 155.

95 Ibid, p. 157.

${ }^{96}$ Harrods Limited v. Harrodian School Limited, [1996] RPC 697 (CA), p. 712.

${ }^{97}$ For example Society of Accountants and Auditors v. Goodway and London Association of Accountants, Limited, [1907] 1 Ch 489; The Law Society of England and Wales v. Society of Lawyers, [1996] FSR 739 (Ch).

${ }^{98}$ For example The Law Society of England and Wales v. Griffiths, [1995] RPC 16 (Ch) in respect of an Accident Helpline service.

${ }^{99}$ The British Diabetic Association v. The Diabetic Society, [1996] FSR 1 (Ch), pp. 10 - 11; Artistic Upholstery Ltd v. Art Forma (Furniture Ltd), [2000] FSR 311 (Ch), p. 325, para. 48.

${ }^{100}$ For example Society of Accountants and Auditors, supra note 97, p. 502; British Medical Association v. Marsh, (1931) 48 RPC 565 (Ch); National Guild of Removers \& Storers Ltd v. Silveria, [2010] EWPCC 015; cf The Law Society of England and Wales, supra note 97, p. 752. See also Whitehead and Kempner 2011.
} 
in charity cases. ${ }^{101}$ While such loss from passing off may be tangible in some cases, it was acknowledged in obiter to be artificially construed to fit within the requirements of the law of passing off. ${ }^{102}$ Courts have also recognised the potential harm in the loss of confidence in the profession or trade as a result of passing off. ${ }^{103}$ The governing bodies carry an authoritative force as well as, particularly for charities, a moral force for their social causes. Such intrinsic value renders them attractive to third party exploitation. Injurious association by appearances of false endorsement ${ }^{104}$ or affiliation ${ }^{105}$ would be detrimental to them. While economic harm is quantifiable, the loss of public confidence is not. ${ }^{106}$ Courts have granted injunctive relief on these occasions. ${ }^{107}$

In the 2002 case of Irvine, Laddie J at the High Court drew on British Medical Association v. Marsh which upheld a passing off claim where the claimant's well-known initials 'B.M.A.', for the non-trade medical professional body, were used by the defendant for the sale of medicine. Laddie J observed in Irvine: 'Thus it was damage to the reputation of the BMA which perfected the cause of action, the loss of membership was the consequence in money terms of that damage. ${ }^{108}$ In Irvine, the claimant's expertise lied in Formula One racing. His success enabled him to leverage his goodwill as a race car driver to diverse endorsement opportunities such as those with HILFIGER for clothing ${ }^{109}$ and GILLETTE for razors, ${ }^{110}$ in sectors beyond his Formula One racing career. ${ }^{111}$ Laddie $\mathrm{J}$ noted that the disputed advertisement did not use an unknown person's photograph, but rather specifically used Irvine's. ${ }^{112}$ It was specifically from the intrinsic value in Irvine's brand appeal that the defendant sports radio station sought to profit. While making doctrinal references to trade mark dilution principles, ${ }^{113}$ Laddie $\mathrm{J}$ further noted the branding practice of associating the 'lustre of a famous personality' with a trader's goods to attract custom. Moreover, Irvine had an existing endorsement public profile. The defendant's advertisement might mislead others to think that the defendant's was among Irvine's paid and approved endorsements. ${ }^{114}$ Prospective business partners might be influenced by this erroneous profile of Irvine

\footnotetext{
${ }^{101}$ British Legion v. British Legion Club (Street) Ld, (1931) 48 RPC 555 (Ch).

${ }^{102}$ Artistic Upholstery Ltd, supra note 99, p. 324, para. 45.

${ }^{103}$ For example The Law Society of England and Wales, supra note 98.

${ }^{104}$ British Medical Association, supra note 100; Scanlan 2003.

${ }^{105}$ British Legion, supra note 101; The Law Society of England and Wales, supra note 97.

${ }^{106}$ The Law Society of England and Wales, supra note 98, p. 22.

107 Society of Accountants and Auditors, supra note 97; British Medical Association, supra note 100; The British Diabetic Association, supra note 99; cf The Society of Architects v. Kendrick, (1910) 25 TLR 433 (Ch).

${ }^{108}$ Irvine (Ch), supra note 3, p. 2362, para. 21

${ }^{109}$ Irvine (CA), supra note 7, p. 631, para. 55.

${ }^{110}$ Ibid, para. 76.

111 Ibid, para. 49.

${ }^{112}$ Ibid, para. 72.

${ }^{113}$ Irvine (Ch), supra note 3, pp. 2366 - 2368, paras. 35 - 38.

${ }^{114}$ Irvine $(\mathrm{Ch})$, supra note 3 , p. 73, para. 73; Irvine (CA), supra note 7, p. 898, paras. 81, 82.
} 
in considering their future engagement with him. The Court of Appeal appreciated the endorsement generated by the intrinsic value in claimant's brand appeal. It substantially increased the award of damages. ${ }^{115}$

By this time, the human rights discourse formed a backdrop of social values against which passing off cases were resolved. High profile cases dealing with third party use of celebrity photographs were making their way through the courts. ${ }^{116}$ The postscript in Irvine ${ }^{117}$ noted that if the law of passing off had not developed sufficiently to cover the false endorsement claim made there, it would have been necessary to invoke the then new strand of law under Human Rights Act 1998, in particular in respect of the right to property ${ }^{118}$ and the right to private and family life. Under Art. 8 of the ECHR, privacy rights encompass a 'right to establish and develop relationships with other human beings and the right to identity and personal development; ${ }^{119}$ they include the right against being cast under a false light. ${ }^{120}$ Cast under a false light, Irvine might suffer in his attempt to establish and develop relationship with others, inter alia for endorsement purposes. Irvine used his endorsements to enhance his image as a racing driver to advance further endorsement opportunities. ${ }^{121}$ Irvine acknowledged that by casting the claimant in the defendant radio station's advertisement, the defendant intended that Irvine's apparent endorsement of the station would make it more attractive to potential listeners and thus advertisers to the radio station. ${ }^{122}$ However, Irvine's own endorsement profile might be affected thereby. The court also recognised that 'the damage already done to Mr Irvine may be negligible in direct money terms, but the potential long-term damage is considerable., ${ }^{123}$

Similarly for the freedom of expression afforded under Art. 10 of the ECHR, scholars have argued within a passing off context that a basic requirement for the realisation of one's autonomy lies in a right not to be displaced with another's expression as one's own. ${ }^{124}$ Furthermore scholars have argued that 'freedom of

\footnotetext{
${ }^{115}$ Irvine (CA), supra note 7, pp. 903 - 904, paras. 111 - 116. Note p. 883, para. 8: Injunctive relief was not sought in this case because the distribution of the disputed advertisement had already ceased.

${ }^{116}$ For example, Douglas v. Hello! Ltd [2001] QB 967 as cited in Irvine (Ch), supra note 3, p. 2379, para. 77; Campbell v. Mirror Group Newspapers Ltd, [2002] IP \& T 612 (QB).

${ }^{117}$ Irvine (Ch), ibid, p. 2379, para. 77.

${ }^{118}$ See text to supra note $66-75$.

${ }^{119}$ Friend, supra note 71, p. 73, para. 41; see 40660/08, 60641/08 Von Hannover v. Germany (No 2), [2012] EMLR 16, 332 (ECtHR (Grand Chamber)), pp. 368 - 369, paras. 108 - 113 for the criteria of balancing ECHR Arts. 8 and 10; see also Campbell v. MGN Ltd, [2004] 2 AC 457 (HL), p. 473, para. 51.

${ }^{120}$ Prosser 1960, pp. 398 - 401; Council of Europe Parliamentary Assembly Resolution 428 (1970) contains a declaration on mass communication on media and human rights [C 2] also cited in Mosley v. UK, Application No. 48009/08, [2012] EMLR 1 (ECtHR), p. 18, para. 56.

${ }^{121}$ Irvine (CA), supra note 7 , p. 892 , paras. $59-60$.

${ }^{122}$ Irvine (Ch), supra note 3, p. 2376, paras. $67-68$, pp. $2377-2378$, paras. $72-73$.

${ }^{123}$ Irvine (Ch), supra note 3, p. 2378, para. 74.

${ }^{124}$ Spence 1996, pp. 497 - 498; Black 2011, pp. $113-115$.
} 
expression includes the right not to be held out as holding views that one finds objectionable. ${ }^{125}$ It includes commercial speech which, though important to inform consumers in a market economy, ${ }^{126}$ is trumped by political speech which directly impacts on the operation of a democratic system which controls the economy. The freedom here includes that for non-speech activities which subtly impart and validate elements of personal identities, social belongings and values. ${ }^{127}$ Passing off also protects claimants from the damaging impact of being falsely perceived as associated with the defendant. ${ }^{128}$ Passing off has been found for the chief executives of an association where a politician falsely claimed membership to the association on his election papers. ${ }^{129}$ Passing off has also been found where a politician's message may be misattributed to a commercial enterprise by using an image of the latter's MARMITE jar in a party political broadcast. ${ }^{130}$ In these contexts, the law appears to be giving increased recognition to the intrinsic values in brands that reach beyond the branded goods. ${ }^{131}$ Similarly, Irvine addressed a false endorsement claim.

\subsection{Goodwill in merchandising}

A year prior to Irvine, Laddie $\mathrm{J}$ delivered a controversial decision on a false merchandising claim in passing off in Arsenal Football Club v. Reed. ${ }^{132}$ His approach here, as in Irvine, was fact-focussed. The defendant had been selling football souvenirs and memorabilia bearing the logo of the claimant's football team for 31 years and had done so on the claimant's grounds for some 15 years. Arsenal took little interest in similar sales for itself until the 1990s when it also registered its logos as trade marks. The defendant claimed that purchasers did not use these logos to determine the provenance of the merchandise, but rather bought the logobearing merchandise to show support for their football team. Laddie $\mathrm{J}$ declared: 'Passing off is concerned with what is happening and what is likely to happen in the marketplace', ${ }^{133}$ or 'the real world of the marketplace'. ${ }^{134}$ He found no actual consumer confusion attributable to the defendant especially in view of the defendant's

\footnotetext{
${ }^{125}$ Burrell and Gangjee 2010, p. 566.

${ }^{126} R$ v. Advertising Standards Authority Ltd, [2001] EMLR 22581 (Admin Court), pp. 595 - 596, para. 28; Miss World Ltd v. Channel Four Television Corp, [2007] ETMR 661044 (Pat), p. 1054, para. 39; Mosley, supra note120, p. 31, para. 114; L'Oréal SA v. Bellure NV, [2010] RPC 23, p. 687 (CA), pp. 692 - 696, paras. 9 - 20; Fhima 2013, pp. 303-304.

${ }^{127}$ Raz 2001, Free expression and personal identification, pp. $153-160$.

${ }^{128}$ Ewing v. Buttercup Margarine Company, Limited, [1917] 2 Ch 1, p. 13; Clock Ltd v. Clockhouse Hotel Ltd, (1936) 53 RPC 269, p. 275; Unitex Limited v. Union Texturing Company Limited, [1972] FSR 489 (Ch) though no injurious association was found on the facts at the motion for interlocutory injunction, affirmed [1973] FSR 181 (CA); Sir Robert McAlpine Ltd v. Alfred McAlpine Plc, [2004] RPC 711 (Ch), p. 722, paras. 19 $-20$.

${ }^{129}$ Burge v. Haycock, [2002] RPC 28 (CA).

${ }^{130}$ Unilever PLC v. Griffin, [2010] FSR 33 (Ch); see also Wadlow 2010.

${ }^{131}$ Cf Kean v. McGivan, [1982] FSR 119 (CA).

132 [2001] RPC 46 p. 922 (Ch).

${ }_{133}$ Ibid, p. 930, para. 23.

${ }^{134} \mathrm{Ibid}$, p. 931, para. 24.
} 
longstanding business and the proximity to the claimant's competing business. ${ }^{135}$ Through the efforts of both parties, purchasers were able to distinguish the 'official' merchandise from the other merchandise sold by the defendant at the point of purchase. ${ }^{136}$ Post-purchase confusion among Arsenal fans bearing official as opposed to unofficial merchandise was not considered. The Court of Appeal was critical of Laddie's decision for relying on outdated principles of passing off ${ }^{137}$ even though passing off was not at issue on appeal; the interpretation of the criticism remains under discussion. ${ }^{138}$ One line of discussion suggests that post-purchase confusion might be considered in future passing off cases. ${ }^{139}$

A decade later in Fenty, the courts found "no difference in the law between an endorsement case and a merchandising case'. ${ }^{140}$ Fenty had goodwill in both the music and fashion industries, as well as involvement in merchandising and endorsement operations. ${ }^{141}$ Two facts appeared to be salient to the courts here: ${ }^{142}$ First, the defendant Topshop had previously featured celebrity endorsements ${ }^{143}$ and promoted Fenty as a fashion icon. ${ }^{144}$ Second, the disputed image was taken when Fenty was on a video shoot for her music album cover. ${ }^{145}$ It would likely mislead some fans familiar with her striking and well-known music album cover to think that the T-shirt bearing the disputed image was a part of her music album project. ${ }^{146}$ While Fenty had her own branded fashion and had endorsed third-party fashion, she had also licensed promotional merchandise including clothing for her concert tours. Such merchandised clothing would typically be of a lower quality and bear the image of the star on the front. In this case, without the goodwill from her music career, the disputed image on the T-shirt alone would not have constituted passing off.

To someone who knew Rihanna [ie Fenty] but did not know her current work, the image is simply one of the person concerned. However to her fans who knew her work, I think this particular image might well be thought to be part of the marketing campaign for that [music video] project. ${ }^{147}$

\footnotetext{
135 Ibid, pp. 931 - 932, para. 26, pp. 933 - 934, para. 32.

${ }^{136}$ Ibid, pp. 935 - 936, paras. 36-43.

${ }^{137}$ Arsenal Football Club Plc v. Reed, [2003] 3 All ER 865 (CA), p. 883 - 884, paras. 70 - 71.

${ }^{138}$ See for example, Wadlow 2006.

${ }^{139}$ O’Byrne and Allgrove 2007.

${ }^{140}$ Fenty $(\mathrm{Ch})$, supra note 8, p. 836, para. 33.

${ }^{141}$ Ibid, respectively p. 839 , para. 46 , p. 837 , para. 38 , and p. 837 , para. 41.

142 Ibid, pp. 842 - 843, para. 63; Fenty (CA), supra note 8, pp. 3297 - 3298, para. 19, p. 3308, para. 52.

${ }^{143}$ Fenty (Ch), supra note 8, p. 841, para. 55; Fenty (CA), supra note 8, p. 3296, para. 16, p. 3308, para. 52.

${ }^{144}$ Fenty (Ch), supra note 8, p. 841, para. 56; Fenty (CA), supra note 8, pp. $3296-3299$, para 17, 19, pp. 3307 -3308 , para. 51 .

${ }^{145}$ Fenty (CA), supra note 8, p. 3293, para. 2, p. 3298, paras. 20-21.

${ }^{146}$ Fenty (Ch), supra note 8, p. 843, para. 69; Fenty (CA), supra note 8, pp. 3298 - 3299, paras. 20-22, pp. 3310 - 3311, para. 61.

${ }^{147}$ Fenty (Ch), supra note 8, p. 843, para. 69.
} 
The Appeal Court cautioned that with awareness of merchandising practices, the public might not necessarily be misled to think the products bearing the image of a famous personality came from the personality. Indeed, different brands relate differently to their consumers, and vice versa. An evidence-based approach in Fenty showed the defendant's activities amounted to a misrepresentation that the claimant had endorsed the goods. ${ }^{148}$ Consistent with recent case law for passing off, ${ }^{149}$ the Appeal Court in Fenty considered two critical hurdles to overcome in a merchandising claim: First, that the use of the name or image had the effect of telling a lie. The use must denote something about the claimant's responsibility over the quality of the defendant's disputed goods. Second, the lie must be sufficiently material, resulting in a purchase decision. ${ }^{150}$ The case considered the potential of both the harm to instrumental value in lost sales to the claimant's merchandising business, and in the harm to intrinsic value through a loss of control over her reputation. ${ }^{151}$

For one thing it amounts to sales lost to her merchandising business. It also represents a loss of control over her reputation in the fashion sphere ... It is a matter for the claimants and not Topshop to choose what garments the public think are endorsed by her. ${ }^{152}$

Thus, by taking a contextual approach, courts are appreciating that the claimant's goodwill in the marketplace not only distinguishes the claimant's goods from those of others. More fundamentally given that the law of passing off requires that the market is already familiar with the claimant's branded goods, the brand may have an intrinsic value in the market place. Its clientele and potential clientele may identify with the brand; its intrinsic value may influence purchase decisions, albeit in diverse trade sectors. Fan interest in ABBA, Arsenal, and Fenty merchandising demonstrates that such brand appeal may extend beyond the claimants' own goods (in music in relation to Fenty). Shortly before delivering his decision in Irvine, Laddie J stated in another passing off decision:

Goodwill is of value, not only in respect of current business, but also because of future business opportunities it will nurture. It is its power to support and improve future business which gives it its value and makes it saleable. It is acquired by trading and advertising in the past but its value is in the way it promotes future business. ${ }^{153}$

\footnotetext{
${ }^{148}$ Fenty (CA), supra note 8, pp. 3304 - 3307, paras. 42 - 47.

${ }^{149}$ Harrods Limited, supra note 96, as cited in Fenty (CA), supra note 8, p. 3305, para. 45.

${ }^{150}$ Fenty (CA), supra note 8, p. 3305, para. 45.

${ }^{151}$ Fenty (Ch), supra note 8 , p. 844 , para. 74.

${ }^{152}$ Fenty (Ch), supra note 8, p. 844, para. 74.

${ }^{153}$ Sutherland v. V2 Music, [2002] IP \& T 904 (Ch), pp. 911 - 912, para. 21.
} 
The instrumental value in a brand facilitates current business and repeat and recommended purchases by enabling purchase decisions to be made based on functional needs. The intrinsic value in a brand can promote, improve, and indeed develop future business by engaging the purchasers' and prospective purchasers' sense of identity and social belonging or aspiration.

Arguably claimants in Clark, McCulloch, ABBA, Irvine, and Fenty desired not only monetary relief, but where applicable, injunctive relief to protect their current income stream and, moreover, to regain control over the intrinsic value in their brands to garner future business. These claimants were cast in the false light of their defendants' advertisements or merchandising; the public might erroneously attribute this casting to the claimants. Being cast in a false light deprives the claimants control over the intrinsic value in their brands, their brands as being 'partly constitutive of a community which is normally a focus of identification.' The recent decisions in Irvine and Fenty recognise that passing off affects not only the instrumental value leading to fungible loss, but also the intrinsic value leading to less quantifiable but potentially longer-term loss.

\section{Goodwill beyond goods:}

This bifurcated approach to goodwill, using Raz's terminology of instrumental and intrinsic value, sees brands not only as sources of consumer information, but also as cultural artefacts with which consumers may identify. Brands inform consumers of the utility of their underlying goods. Thereby they promote their goods to customers. This instrumental value in brands remains with their goods. By becoming a point of identity for consumers and providing a sense of social belonging or aspiration (for example, by McDonald's restaurants offering cobranded games for children and supporting children welfare charities, ${ }^{154}$ or in its 'Forever Young' campaign, by its mascot appearing with sports stars ${ }^{155}$ ), brands may also acquire an intrinsic value. They can mobilise a collective (respectively, the traditional toddlers-and-parents market and the new health conscious young adult market). The identity of that collective further informs the brand's identity.

In this way, similar social dynamics as those analysed here vis-à-vis claimants whose personal identities are at stake may apply to corporate (as opposed to personal) brands. Corporate brands do not suffer human indignities; they are also alienable. Nevertheless, they too need to be protected from being cast under a false light because their intrinsic value depends on their ability to appeal to and be 'partly constitutive of a community [of individuals] which is normally a focus of identification'. ${ }^{156}$ When cast under a false light, brands lose control over their attraction for spokespersons and role models, and reference and peer consumers who

\footnotetext{
${ }^{154}$ See text to supra notes $82-83$.

155 See text to supra note 38 .

${ }^{156}$ See text to supra note 28
} 
would appeal to their target markets or be a part of those markets. In addition to protecting the goodwill of the professional and trade governing and promoting bodies as discussed earlier, within commercial contexts, courts have granted relief to protect not only the immediate purchasers, but also the final consumers, the suppliers, and the sponsoring advertisers who may be confused under passing off. ${ }^{157}$ By assessing passing off in the broader context of what Laddie $\mathrm{J}$ termed the 'real world of the marketplace', courts are coming to terms with the protection in not only of the instrumental value in brands, but also their intrinsic value. It is arguably this intrinsic value which defendants such as those in Clark, McCulloch, ABBA, Irvine, and Fenty have sought to exploit, and the claimants have sought to protect. While these claimants' personal identities were at stake in these cases, as the law of passing off protects only pre-existing goodwill, such goodwill in corporate brands are often associated with or negotiated through individuals - as designated or volunteer spokespersons, role models, reference and peer consumers. It is these individuals who would inhabit or represent a corporate brand, and showcase a narrative for it. It is these individuals with whom prospective consumers would identify and join as constituents of a brand, or with whom prospective business partners would associate. It is these individuals who help influence or even drive purchase or business decisions. These individuals may shun a brand that has been cast under a false light, as shown in the cases that protect the goodwill of the professional and trade governing and promoting bodies.

Goodwill was initially cast as property by early claimants who desired injunctive over monetary relief; the Courts of Chancery alone could grant injunctive relief and they also had clear jurisdiction to uphold proprietary interests. What passing off claimants then and now seek to protect however is not only the static instrumental value in their brands to distinguish their goods from others'. Goods are fungible; lost sales are quantifiable and may be remedied monetarily. The passing off claimants seek injunctive relief to protect the intrinsic value in their brands. This concern is forward looking. This wider brand appeal imbued with social values and meanings as a point of identity for target markets allows claimants to mobilise and marshal their clientele and develop new clientele. Once the brand is launched, the social values and meanings represented in its promotional efforts, by its spokespersons, as well as its consumers and commentators continue to inform the brand. Claimants are eager to ensure that those whose purchase or business decisions their brands may

\footnotetext{
${ }^{157}$ For example, with final consumers: F Hoffman-La Roche \& Company AG v. DDSA Pharmaceuticals Limited, [1969] FSR 410 (CA); with suppliers: R\&J Pullman Ld v. Pullman, (1919) 36 RPC 240 (Ch); Chelsea Man Menswear Limited v. Chelsea Girl Limited, [1987] RPC 189 (CA) pp. 205 - 206; and with sponsoring advertisers: Tamworth Herald Company Ltd v. Thomson Free Newspapers Ltd, [1991] FSR 337 (Ch); Management Publications Limited v. Blenheim Exhibitions Group Plc, [1991] FSR 550 (CA); MorganGrampian Plc v. Training Personnel Limited, [1992] FSR 267 (Ch); cf Plentyoffish Media Inc, [2012] RPC 5 (Ch) in the context of free website services supported by paid sponsors.
} 
influence are engaging with their brand identities, not identities that are manipulated by third parties and that are falsely attributed to the claimants, or identities that cast the claimants in a false light. Claimants desire to control their goodwill so that they may retain the integrity of their going-concerns to plan for the future. The instrumental value in brands to distinguish their goods from others' serves to retain this control as status quo; the intrinsic value in brands helps brands to marshal their clientele and to develop future clienteles.

\section{Conclusion:}

The law of passing off too may be viewed in this bifurcated way. The instrumental value in the law lies in its role in ensuring that a trader does not pass off his or her goods as those of another. To remain relevant in the minds of its constituents and to remain intrinsically valuable, it is 'closely connected to and dependent upon what is happening in the market place. ${ }^{158}$ As a part of unfair competition law or economic tort, ${ }^{159}$ the law has as an 'underlying principle ... the maintenance of what is currently regarded as fair trading. [It] responds to changes in the nature of trade. ${ }^{160}$ The law has evolved to increasingly take into account the intrinsic value in brands as points of identity. For example, the intrinsic value carried arguably in reference to Clark, presumably for his status as Physician in Ordinary to the Queen and a specialist in consumption, was dismissed in Clark. $^{161}$ That carried arguably in reference to 'Uncle Mac', presumably for the claimant's radio appeal to children, was dismissed in McCulloch. ${ }^{162}$ The instrumental value of the claimants' brands was not at issue in these cases. The disputing parties did not operate within a common field, and so there was no passing off by way of a goods-forgoods substitution. Developments in the law of passing off as well as those toward and in trade mark licensing allowed traders to take advantage of the intrinsic value in their brands to serve not only a product segment, but a market segment which embraces the lifestyle narrative and broader social values of their consumers.

The intrinsic value in brands is however difficult to conceptualise in legal terms. Recent courts account for it and overcome the idea of requiring a common field between the disputing parties by taking a contextual approach to consider the social dynamics between consumers and the claimants' brands in the creation of goodwill in the market place. Under Raz's conception, the law would be all the more compelling if its constituents would identify with it and where it is consonant with the broader political and social reality. The recent developments in the law of passing off, especially as they pertain to personal identities in Irvine and Fenty, coincided and appear consonant with the broader developments in human rights law in the UK. These

\footnotetext{
${ }^{158}$ Irvine (Ch), supra note 3, p. 2360, para. 13.

${ }^{159}$ Carty 2012; Wadlow 2011, pp. 2 - 7, paras. 1-001 - 1-009, 1-013; Carty 2010, pp. 28 - 37.

${ }^{160}$ Irvine (Ch), supra note 3, p. 2361, para. 14.

${ }^{161}$ See text to supra notes $50-53$.

162 See text to supra notes $84-85$.
} 
developments in human rights law help affirm those in the law of passing off as an integral part of the broader political and social reality and the social values that lie therein. These developments in human rights law also help explain how the intrinsic value of brands may be affected in passing off. While the human right to property in goodwill as interpreted under Art. 1 of Protocol 1 to the ECHR limits the claim and takes a mere snapshot of the accrued income or that within a 'legitimate expectation' at a relevant date, it may serve as a backstop to enable the fulfilment of other human rights ${ }^{163}$ such as the rights to privacy and to free speech ${ }^{164}$ recognised respectively under Arts. 8 and 10 of the ECHR. The former protects the right to establish and develop relationships with others and the right to identity and personal development. ${ }^{165}$ It includes the right against being cast under a false light. The latter also protects the right not to be displaced with another's expression as one's own. ${ }^{166}$ Passing off protects claimants from being cast under a false light or being falsely perceived as professionally associated with the defendant. It protects the claimants' goodwill and with it, the claimant's professional relationships. Recent case law maintains that to constitute passing off, the use of the claimant's name or image must have the effect of telling a lie to denote the claimant's endorsement of the defendant's advertisement or goods, and that lie must be sufficient to result in a change in purchase decisions or other professional dealings with the claimant. ${ }^{167}$ By taking a contextual approach in Irvine and Fenty, the courts considered the social dynamics between brands and their relevant public, and how these dynamics may be altered as a result of the misrepresentation.

The English law of passing off is not protean. Rather, the claimants' concerns have been consistent throughout in Clark, McCulloch, ABBA, Irvine, and Fenty. They wish to regain control over not only the instrumental value but also the intrinsic value in their brands. Even though this intrinsic value may be difficult to conceptualise in law, by taking a contextual approach, the courts are applying doctrines from the law of passing off with a fuller appreciation of the claimants' concerns. Informed by this fuller understanding of the market place and consonant with the broader social values from the human rights discourse in the backdrop, the law of passing off maintains its relevance and its intrinsic value among its constituents. As it enforces a standard of fair trading, it also embodies a standard that is accepted by its constituents and affirms their social values. The law of passing off too has both instrumental and intrinsic value. It manifests and enforces a social

\footnotetext{
${ }^{163}$ Hayward 2013; Reiss 2011, pp. 189 - 190; see also Fhima 2013, pp. 296 - 297, 312, 319; Raz 2001, Rights and individual well-being, p. 49.

${ }^{164}$ See also Patel v. Allos Therapeutics Inc, [2008] ETMR $75(\mathrm{Ch})$ for the need to balance between property right and the freedom of expression.

${ }^{165}$ See text to supra notes 116 - 123.

${ }^{166}$ See text to supra notes $124-131$.

${ }^{167}$ See text to supra notes 89 - 96.
} 
norm. As it is applied in view of contemporary branding practices and social dynamics in a way that is consonant with the broader social values, it is also forward looking.

\section{Acknowledgements}

This paper has benefitted enormously from the gracious and generous comments from (in alphabetical order) Theodoros Chiotis, Christopher Floyd, Dev Gangjee, Tamas Gyorfi, Louis Harms, the IIC editors, Colin Mackie, David Vaver, and Sharon Wong who have reviewed early drafts of this work, and members of the audience with whom I have discussed a part of this paper at an Oxford Intellectual Property Research Centre (OIPRC) seminar chaired and organised by Emily Hudson. It has also benefitted enormously from the discussions at the Oxford Trade Mark Scholars Roundtable 2015 at the OIPRC organised by Graeme Dinwoodie and Dev Gangjee. All infelicities remain mine alone. I am very grateful for the Carnegie research grant which has facilitated part of the research in this work.

\section{References}

Balganesh S and Parchomovsky (2015) Structure and value in the common law. U Penn LR 163:1242 - 1310

Bently L (2008) The making of modern trade mark law: the construction of the legal concept of trade mark (1860-1880). In: Davis J et al (eds), Trade marks and brands, Cambridge University Press, Cambridge, pp. 3 41

Bhasin A (2012) Future income versus goodwill under A1P1 - a distinction without a difference? JR 17(3):226 $-235$

Black G (2011) Publicity rights and image - exploitation and legal control. Hart publishing, Oxford

Blythe A (2015) In search of Mr Average: attempting to identify the average consumer and his role within trade mark law. EIPR 37(11):709 - 715

Bone RG (2006) Hunting goodwill: a history of the concept of goodwill in trademark law. Boston U LR $86: 547-622$

Breazeale M and Fournier S (2012) Musings and meditations: where do we go from here? In Fournier S et al (eds), Consumer-brand relationships: theory and practice, Routledge Taylor \& Francis Group, London, pp. 395 $-412$

Brudner A (2013) The unity of the common law. Oxford University Press, Oxford

Burrell R and Gangjee D (2010) Trade marks and freedom of expression - a call for caution. IIC 41(5):544 569

Carty H (2012) Passing off: frameworks of liability debated. IPQ 2:106 - 122

Carty H (2010) An analysis of the economic torts. Oxford University Press, Oxford

Chronopoulos A (2011) Determining the scope of trademark rights by recourse to value judgements related to the effectiveness of competition - the demise of the trademark-use requirement and the functional analysis of trademark law. IIC 42(5):536 - 570 
Cornthwaite J (2012) Say it with flowers: the judgement of the Court of Justice of the European Union in Interflora v. Marks \& Spencer. EIPR 34(2):127 - 132

Corporate Design Foundation (2006-2007) Burnishing the golden arches. @Issue 12(1):8 - 15. http://studiohinrichs.com/atissue/atissue_12.1.pdf. Accessed 28 March 2016

Davis J and Maniatis S (2010) Trademarks, brands, and competition. In: da Silva Lopes T, Duguid P (eds) Trademarks, brands, and competitiveness. Routledge International Studies in Business History, Abingdon, pp. $119-137$

De Landa Barajas A (2009) Personality rights in the US and the UK - is Vanna too much? Is Irvine not enough? Ent LR 20(7):253 - 258

Dinwoodie GB (2014) Dilution as unfair competition: European echoes. In: Dreyfuss R, Ginsburg J (eds) Intellectual property at the edge: the contested contours of IP. Cambridge University Press, Cambridge, pp. 81 $-102$

Douglas M and Isherwood B (1979) The world of goods. Basic Books, New York

Dupont J-B (2013) Uncharted territories of trade mark use. IPQ 2:139 - 165

Dworkin R (1998) Law’s empire. Hart Publishing, Oxford

Edvardsson B et al (2011) Expanding understanding of service exchange and value co-creation: a social construction approach. J of the Academy of Marketing Science 39(2):327 - 339

Fhima IS (2013) Trade marks and free speech. IIC 44(3):293 - 321

Geiger C (2009) Intellectual property shall be protected!? Article 17(2) of the Charter of Fundamental Rights of the European Union: a mysterious provision with an unclear scope. EIPR 31(3):113 - 117

Griffiths J (2015) On the back of a cigarette packet: standardised packaging legislation and the tobacco industry's fundamental right to (intellectual) property. IPQ 4:343 - 369

Hale B (2013) The protection of human rights in the United Kingdom. Oxford U Comparative L Forum 1, http://ouclf.iuscomp.org/articles/hale.shtml. Accessed 28 March 2016

Hart HLA (2012) The concept of law. Clarendon Law Series, Oxford

Hayward T (2013) Human rights vs property rights. JWI Working Paper No. 2013/04, http://www.sps.ed.ac.uk/ data/assets/pdf_file/0005/129911/Tim_Hayward_JWI_Working_Paper_Human_righ ts_vs_property_rights.pdf. Accessed 28 March 2016

Klink J (2003) 50 years of publicity rights in the United States and the never ending hassle with intellectual property and personality rights in Europe. IPQ 4:363 - 387

Kur A (2014) Trade marks function, don't they? CJEU jurisprudence and unfair competition principles. IIC 45(4):434 - 454

Light L and Kiddon J (2009) Six rules for brand revitalization - learn how companies like McDonald's can reenergize their brands. Person Education, New Jersey

Lury C (2007) Consumer culture, reprint. Polity Press, Cambridge

MacCormick N (2005) Rhetoric and the rule of law - a theory of legal reasoning. Oxford University Press, Oxford

McKenna MP (2006-2007) The normative foundations of trademark law. Notre Dame LR 82:1839 - 1916 
Ni Shuilleabhain M (2003) Common-law protection of trade marks - the continuing relevance of passing off. IIC 34(7):722 - 750

O’Byrne P and Allgrove B (2007) Post-sale confusion. Journal of Intellectual Property Law \& Practice 2:5:315 $-323$

Prosser WL (1960) Privacy. Calif LR 48:383 - 423

Radin MJ (1981-1982) Property and personhood. Stanford LR 34:957 - 1015

Raz J (2001) Rights and individual well-being in Raz J (ed) Ethics in the public domain, revised edn. Clarendon Press, Oxford, pp. $43-59$

Raz J (2001) Free expression and personal identification in Raz J (ed) Ethics in the public domain, revised edn. Clarendon Press, Oxford, pp. $146-169$

Raz J (2009) Between authority and interpretation - on the theory of law and practical reason. Oxford University Press, Oxford

Reiss JW (2011) Commercializing human rights: trademarks in Europe after Anheuser-Busch v Portugal. JWIP 14(2):176 - 201

Scanlan G (2003) Personality, endorsement and everything: the modern law of passing off and the myth of the personality right. EIPR 25(12):563 - 569

Schmitt B (2012) The consumer psychology of brands. J of Consumer Psychology 22:7 - 17

Senftleben M (2014) Function theory and international exhaustion: why it is wise to confine the double identity rule in EU trade mark law to cases affecting the origin function. EIPR 36(8):518 - 524

Senftleben M et al (2015) The recommendation on measures to safeguard freedom of expression and undistorted competition: guiding principles for the further development of EU trade mark law. EIPR 37(6):337 - 343

Sermet L (1998) The European Convention on Human Rights and Property Rights. Council of Europe Publishing, http://www.echr.coe.int/LibraryDocs/DG2/HRFILES/DG2-EN-HRFILES-11(1998).pdf. Accessed 28 March 2016

Sherman and Bently (1999) The making of modern intellectual property law - the British experience, 1760 1911. Cambridge University Press, Cambridge

Schwarzkopf S (2010) Turning trademarks into brands - how advertising agencies practiced and conceptualized branding, 1890 - 1930. In: da Silva Lopes T, Duguid P (eds) Trademarks, brands, and competitiveness. Routledge International Studies in Business History, Abingdon, pp. 165 - 193.

Spence M (1996) Passing off and the misappropriation of valuable intangibles. LQR 112:472 - 498

Vaver D (2006) Advertising using an individual's image: a comparative note. LQR 122:362 - 369

Wadlow C (2006) One more outing for Arsenal: a case of dilution or one for restitution? JIPLP 1:143 - 147

Wadlow C (2010) The Marmite election. JIPLP 6(12):868 - 879

Wadlow C (2011) The law of passing-off: unfair competition by misrepresentation. $4^{\text {th }}$ edn. Sweet \& Maxwell, London

Walsh C (2013) Are personality rights finally on the UK agenda? EIPR 35(5):253 - 260

Whitehead B and Kempner R (2011) Can you recover money when there are no lost sales and no profits? JIPLP $6(4): 216-217$ 
Wolter JS et al (2016) Symbolic drivers of consumer-brand identification and disidentification. J of Business Research 69(2):785 - 793

Yap PJ (2009) Essential function of a trade mark: from BMW to O2. EIPR 31(2):81 - 87 